\title{
Kesan Polifenol Minyak Kelapa Dara ke atas Aktiviti Enzim Antioksidan dan Lipid Peroksida Pada Sel Osteoblas
}

(Virgin Coconut Oil Polyphenol Effects on Antioxidant Enzyme Activities and Lipid Peroxidation on Osteoblast Cell)

\author{
ZIL HAYATULLINA, NORAZLINA MOHAMED, IMA-NIRWANA SOELAIMAN \& NORLIZA MUHAMMAD*
}

\begin{abstract}
ABSTRAK
Osteoporosis dikaitkan dengan radikal bebas dan tekanan oksidatif. Kandungan polifenol yang tinggi dalam minyak kelapa dara (VCO) yang bertindak sebagai antioksidan mampu menghalang tekanan oksidatif seterusnya mencegah osteoporosis. Uji kaji in vitro ini dijalankan untuk mengkaji mekanisme kesan perlindungan polifenol ekstrak daripada VCO (PF) ke atas sel selanjar pre-osteoblas mencit (MC3T3-E1) teraruh tekanan oksidatif. Untuk mengkaji viabiliti kesan perlindungan polifenol terhadap MC3T3-E1 daripada toksisiti hidrogen peroksida $\left(\mathrm{H}_{2} \mathrm{O}_{2}\right)$, sel MC3T3-E1 dirawat dengan beberapa dos polifenol selama 24 jam selepas dieram dengan $250 \mu \mathrm{M}\left(\mathrm{IC}_{50}\right) \mathrm{H}_{2} \mathrm{O}_{2}$ selama 1 jam. Mekanisme perlindungan dikaji dengan mengukur aras malondialdehid (MDA) serta aktiviti enzim antioksidan iaitu superoksida dismutase (SOD), glutation peroksidase (GPX) dan katalase (CAT). Keputusan kajian menunjukkan bahawa kepekatan perencatan median $\left(\mathrm{IC}_{50}\right) \mathrm{H}_{2} \mathrm{O}_{2}$ pada 1 jam adalah $250 \mu \mathrm{M}$. Ujian viabiliti sel mendapati kesemua dos polifenol dapat melindungi sel MC3T3-E1 daripada toksisiti $\mathrm{H}_{2} \mathrm{O}_{2}$. Dos 1 dan $0.01 \mu \mathrm{M}$ polifenol dapat meningkatkan aras GPx dan CAT, manakala dos 0.01 dan 0.0001 MM dapat meningkatkan aras SOD. Sementara itu, hanya dos 0.01 dan 0.001 MM sahaja yang dapat menghalang peningkatan aras MDA. Kesimpulan yang dapat dibuat di dalam kajian ini adalah polifenol daripada minyak kelapa dara mencegah lipid peroksida pada sel MC3T3-E1 yang telah diaruh dengan $\mathrm{H}_{2} \mathrm{O}_{2}$ dengan meningkatkan aktiviti enzim antioksidan.
\end{abstract}

Kata kunci: Osteoporosis; polifenol; sel MC3T3-E1; tekanan oksidatif; VCO

\section{ABSTRACT}

Osteoporosis is associated with free radicals and oxidative stress. The high polyphenol contents in virgin coconut oil ( $V C O)$ can prevent oxidative stress and consequently osteoporosis. This in vitro study was conducted in order to determine the mechanism of the protective effects of polyphenol extracted from VCO on murine osteoblast-like cell line (MC3T3-E1) which was induced with oxidative stress. To study the protective effects on viability of MC3T3-E1 cells exposed to hydrogen peroxide $\left(\mathrm{H}_{2} \mathrm{O}_{2}\right)$ toxicity, MC3T3-E1 cells were post-treated with different doses of polyphenol for $24 \mathrm{~h}$ after 1 $h$ incubation with $250 \mu \mathrm{M}$ of $\mathrm{H}_{2} \mathrm{O}_{2}\left(\mathrm{IC}_{50}\right)$. The protective mechanism was studied by measuring melondialdehyde (MDA) levels as well as antioxidant enzymes activities which are superoxide dismutase (SOD), glutathione peroxidase (GPX) and catalase (CAT). The results showed that the median inhibitary concentration $\left(\mathrm{IC}_{50}\right)$ for $\mathrm{H}_{2} \mathrm{O}_{2}$ after $1 \mathrm{~h}$ was $250 \mu \mathrm{M}$. Cell viability tests showed that all the doses of polyphenol were able to protect MC3T3-E1 cells from $\mathrm{H}_{2} \mathrm{O}_{2}$ toxicity. The dose of 1 and $0.01 \mu \mathrm{M}$ of polyphenol increased the level of GPX and CAT while the dose of 0.01 and $0.0001 \mu M$ increased the level of SOD. Meanwhile, the $0.0001 \mu \mathrm{M}$ of PF prevented the MDA elevation. In conclucion, the polyphenol components in virgin coconut oil prevent lipid peroxidation in MC3T3-E1 cells induced with $\mathrm{H}_{2} \mathrm{O}_{2}$ by increasing the endogenous antioxidant enzymes.

Keywords: MC3T3-E1 cells; osteoporosis; oxidative stress; polyphenol; VCO

\section{PENGENALAN}

Osteoporosis ialah sejenis penyakit metabolik tulang yang bercirikan pengurangan jisim tulang dan gangguan mikroarkitektur pada tulang. Hal ini menyebabkan kekuatan dan ketumpatan tulang semakin berkurang, lalu menjurus kepada kepatahan tulang (Daroszewska 2015). Osteoporosis dikenali sebagai penyakit yang senyap kerana ia tidak memberikan masalah kepada penderitanya sehinggalah kepatahan tulang berlaku (Cosman et al. 2014). Masalah osteoporosis semakin menular dalam kalangan masyarakat terutamanya kepada wanita pascamenopaus seiring dengan pertambahan jangka hayat dan umur populasi penduduk dunia. Selepas seseorang wanita mengalami menopaus, hormon estrogen semakin berkurang dan ini menyebabkan aktiviti osteoklastik di dalam tulang melebihi aktiviti osteoblastik (Norliza et al. 2012). Apabila keadaan ini berlaku, seseorang wanita itu perlu berhati-hati kerana tulang menjadi semakin rapuh dan risiko mendapat kepatahan tulang adalah tinggi (McNamara 2010).

Selain daripada penurunan fungsi endokrin dalam kalangan wanita pascamenoapus, beberapa faktor 
lain seperti nutrisi, genetik serta faktor fizikal juga memainkan peranan yang penting di dalam patogenesis osteoporosis. Di samping itu, osteoporosis juga dikaitkan dengan tekanan oksidatif, iaitu keadaan di mana terdapat kerosakan pada sel terutamanya kepada komponen membran sel, protein dan lipid akibat aktiviti radikal bebas yang melampau (Danielle et al. 2015). Kajian terdahulu mendapati tekanan oksidatif mempengaruhi fungsi dan aktiviti kedua-dua jenis sel tulang yang penting iaitu osteoblas dan osteoklas, terutamanya dalam meningkatkan pembezaan dan mengaktifkan fungsi osteoklas lalu menjurus kepada kehilangan jisim tulang (Baek et al.2010). Aktiviti radikal bebas yang berlebihan menyebabkan penurunan aras antioksidan dan ketumpatan mineral tulang (BMD) terutamanya kepada lelaki yang berusia serta wanita yang yang telah mencapai status menopaus (Altindag et al. 2008; Sendur et al. 2009). Kajian juga mendapati kekurangan antioksidan seperti vitamin E boleh menyebabkan impak negatif kepada kesihatan tulang dan pengambilan antioksidan boleh mencegah dan merawat kehilangan jisim tulang (Muhammad et al.2010). Fakta ini turut disokong oleh Morton et al. (2001) yang mendapati terdapat peningkatan pada nilai BMD apabila wanita pascamenopaus mengambil suplemen antioksidan jenis Vitamin C.

Minyak kelapa dara lebih istimewa daripada minyak kelapa biasa kerana mempunyai kandungan vitamin dan antioksidan yang tinggi memandangkan ia diekstrak daripada santan kelapa melalui proses penapaian tanpa melibatkan penggunaan haba (Marina et al. 2009). Beberapa kajian terdahulu menunjukkan keajaiban minyak ini dalam menghalang pembentukan sel kanser (Manisha \& Shyamapada 2011) di samping sifat antiviral (Arora et al. 2011), antibakteria (Oyi et al. 2010), antikaries (Taheri et al. 2010), antiplak (Barnabe et al. 2004) dan antiprotozoa (Sosknowska \& Balslev, 2009). Kajian kami sebelum ini turut membuktikan kesan positif minyak kelapa dara terhadap metabolisme tulang kerana ia mencegah kehilangan jisim tulang serta meningkatkan aras antioksidan endogenous dalam tulang tikus model osteoporosis (Abujazia et al. 2012; Zil Hayatullina et al. 2012). Kandungan antioksidan jenis polifenol yang tinggi dalam minyak kelapa dara ini didapati bertanggungjawab dalam menghasilkan kesan farmakologinya (Nevin \& Rajamohan 2005). Sehingga kini, hanya terdapat sebilangan kecil penyelidik yang mengkaji mekanisme cara tindak polifenol ke atas unsur biologi. Sepanjang pengetahuan kami, kajian ini adalah kajian yang pertama yang mengkaji kesan komponen fenolik minyak kelapa dara terhadap sel pembentukan tulang iaitu sel osteoblas.

\section{BAHAN DAN KAEDAH KAJIAN}

\section{PENGKULTURAN SEL}

Sampel yang digunakan adalah sel selanjar pre-osteoblas menyerupai mencit (MC3T3-E1) yang dibeli dari
American Type Culture Collection (ATCC), USA dan dikultur di dalam Alpha Minimum Essential Medium $(\alpha$-MEM) yang mengandungi deoksiribonukleosida, 2 $\mathrm{mL}$ L-glutamin dan $1 \mathrm{mM}$ Natrium piruvat, tetapi tidak mengandungi asid askorbik yang dibeli dari GIBCO BRL (Grand Island, NY, USA). Alpha-MEM ini ditambah dengan $10 \%$ serum bovin fetal dan disuplementasi dengan antibiotik 50 unit $/ \mathrm{mL}$ penisilin dan $50 \mu \mathrm{g} / \mathrm{mL}$ streptomisin. Sel MC3T3-E1 disubkultur di dalam kelalang $75-\mathrm{cm}^{2}$ sehingga mencapai $80 \%$ konfluen dalam masa 3 hari di dalam mesin inkubator karbon dioksida (5\% $\mathrm{CO}_{2} / 95 \%$ udara) pada suhu $37^{\circ} \mathrm{C}$.

\section{PENGEKSTRAKAN POLIFENOL MINYAK KELAPA DARA (PF)}

Polifenol minyak kelapa dara diekstrak berdasarkan kaedah Nevin dab Rajamohan (2004). Secara ringkasnya, 10 g vCO dilarutkan di dalam $50 \mathrm{~mL}$ cecair heksana. Kemudian, campuran tersebut diekstrak dengan menggunakan $60 \%$ methanol sebanyak $60 \mathrm{~mL}$. Pengekstrakan dengan $60 \%$ methanol dibahagikan kepada 3 dengan $20 \mathrm{~mL}$ setiap 2 minit. Campuran ekstrak VCO dikeringkan dengan menggunakan mesin penyejat berputar pada suhu $40^{\circ} \mathrm{C}$.

\section{ARUHAN HIDROGEN PEROKSIDA DAN RAWATAN POLIFENOL VCO}

Sebelum memulakan kajian, kesan sitotoksisiti $\mathrm{H}_{2} \mathrm{O}_{2}$ dan polifenol VCO terhadap viabiliti sel dibuat dengan menggunakan kit asai proliferasi sel (MTS) (Abcam). Sejumlah $1 \times 10^{4} \mathrm{sel} / \mathrm{cm}^{2}$ sel MC3T3-E1 dikultur di dalam media kultur lengkap (CCM) pada 96-telaga plat mikrotiter sehingga mencapai $80 \%$ konfluen. Beberapa siri kepekatan $\mathrm{H}_{2} \mathrm{O}_{2}$ daripada 0 sehingga $100 \mu \mathrm{M}$ telah ditambah ke dalam setiap telaga selama 1 jam. Untuk melihat kesan perlindungan dan rawatan polifenol minyak kelapa dara (PF) terhadap sitotoksisiti sel MC3T3-E1 aruhan $\mathrm{H}_{2} \mathrm{O}_{2}$ pula, sel MC3T3-E1 akan dieram dengan $\mathrm{H}_{2} \mathrm{O}_{2}$ berdasarkan kepekatan yang telah dipilih sebelum dirawat dengan beberapa siri kepekatan PF $(0.0001-0.1 \mu \mathrm{g} / \mathrm{mL})$ selama 24 jam. Medium mengandungi $\mathrm{H}_{2} \mathrm{O}_{2}$ perlu dibuang terlebih dahulu sebelum rawatan PF ditambah ke dalam plat telaga. Pengukuran Aktiviti Enzim Antioksidan dan malondialdehid (MDA)

Sel MC3T3-E1 dikultur pada ketumpatan $2 \times 10^{5}$ sel/mL di dalam CCM sehingga mencapai $70 \%$ konfluen. Kemudian, sel MC3T3-E1 itu dikultur di dalam media kultur pembezaan selama 15 hari sebelum sel didedahkan dengan aruhan $\mathrm{H}_{2} \mathrm{O}_{2}$. Media kultur pembezaan disediakan dengan mencampurkan media $\alpha$-MEM dengan $10 \%$ serum bovin fetal, $1 \%$ penisilin/streptomisin, $5 \mathrm{mM}$ $\beta$-gliserofosfat dan $50 \mu \mathrm{g} / \mathrm{mL}$ asid askorbik. Sel MC3T3-E1 dirawat dengan PF selama 24 jam. Setelah itu, sel diambil untuk menjalani parameter aktiviti enzim antioksidan dengan menggunakan kit asai Superoksida dismutase (SOD), Glutation Peroksidase (GPx) dan Katalase (CAT) dibeli dari Cayman Chemical, USA. Kit malondialdehid (MDA) pila dibeli dari Biovision, USA). 


\section{ANALISIS STATISTIK}

Analisis data dilakukan dengan menggunakan perisian computer 'Statistical Package for Social Sciences' (SPSS 19.0, Chicago, IL, USA). Data yang diperoleh diuji kenormalannya dengan ujian Kolmogorov-Smirnov. Data taburan normal dianalisis dengan menggunakan ujian parametric ANOVA dan disusuli dengan Tukey's hsd. Data yang bertaburan tidak normal pula dianalisis menggunakan ujian tak-parametrik Kruskal-Wallis dan Mann-Whitney U. Kesemua keputusan kajian dikemukakan dalam bentuk min \pm ralat min piawai (SEM).

\section{KEPUTUSAN KAJIAN}

Rajah 1 menunjukkan kesan sitotoksisiti $\mathrm{H}_{2} \mathrm{O}_{2}$ terhadap sel selanjar pre-osteoblas mencit (MC3T3-E1) selepas rawatan selama 1 jam. Dalam kajian ini, didapati bahawa viabiliti sel MC3T3-E1 menurun apabila kepekatan
$\mathrm{H}_{2} \mathrm{O}_{2}$ meningkat. Penurunan viabiliti sel berlaku secara signifikan $(p<0.05)$ apabila sel MC3T3-E1 dirawat dengan $\mathrm{H}_{2} \mathrm{O}_{2}$ yang berkepekatan melebihi $250 \mu \mathrm{M}$ berbanding kumpulan kawalan. Rawatan $\mathrm{H}_{2} \mathrm{O}_{2}$ yang berkepekatan melebihi $250 \mu \mathrm{M}$ selama satu jam menurunkan viabiliti sel MC3T3-E1 melebihi 50\%. Didapati bahawa $\mathrm{IC}_{50}$ bagi sel MC3T3-E1 yang didedahkan dengan $\mathrm{H}_{2} \mathrm{O}_{2}$ selama satu jam adalah $250 \mu \mathrm{M}$.

Kesan rawatan polifenol yang diekstrak daripada minyak kelapa dara terhadap sel MC3T3-E1 ditunjukkan pada Rajah 2. Keputusan kajian menunjukkan kesemua dos PF iaitu 0.1, 0.01, 0.001 dan $0.0001 \mu \mathrm{g} / \mathrm{mL}$ dapat meningkatkan viabiliti sel MC3T3-E1 secara signifikan $(p<0.05)$ setelah didedahkan pada $250 \mu \mathrm{M} \mathrm{H}_{2} \mathrm{O}_{2}$ selama satu jam. Walau bagaimanapun, tiada dos PF yang menurunkan viabiliti sel MC3T3-E1 berbanding kumpulan kawalan. Oleh kerana dos PF $(0.1,0.01,0.001$ dan 0.0001 $\mu \mathrm{g} / \mathrm{mL}$ ) yang diberikan kepada sel MC3T3-E1 tidak

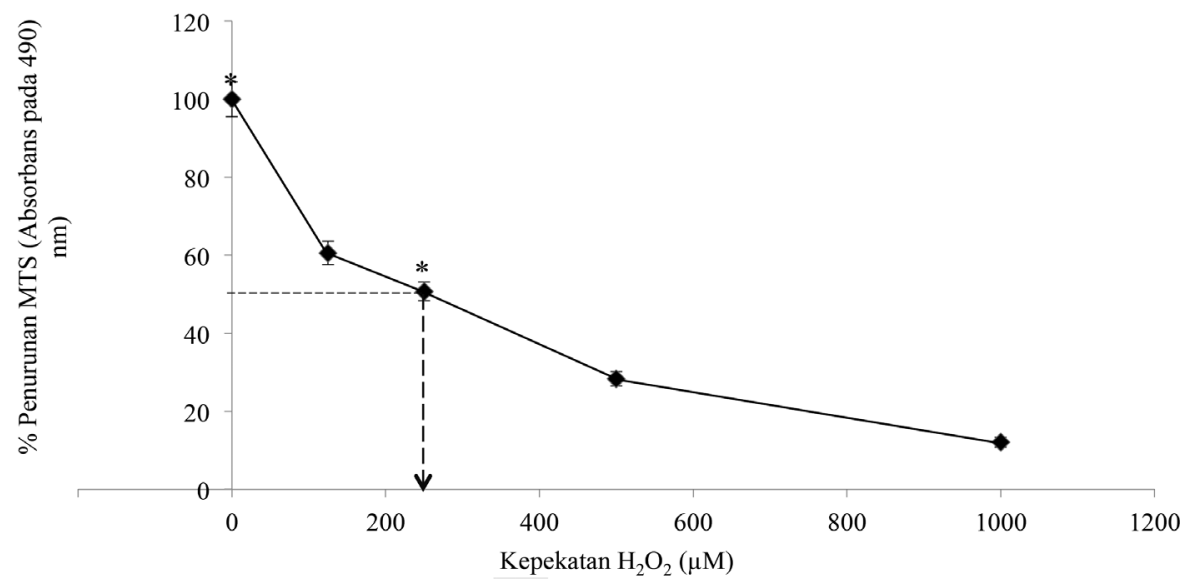

Simbol (*) menunjukkan bahawa nilai berbeza secara signifikan $(p<0.05)$ dengan kumpulan kawalan (kepekatan 0$)$

RAJAH 1. Kesan toksisiti $\mathrm{H}_{2} \mathrm{O}_{2}$ terhadap sel selanjar pre-osteoblas mencit (MC3T3-E1) ditentukan dengan menggunakan asai MTS. Sel MC3T3-E1 didedahkan dengan $\mathrm{H}_{2} \mathrm{O}_{2}$ selama 1 jam. Didapati $\mathrm{IC}_{50}$ bagi 1 jam adalah $250 \mu \mathrm{M}$

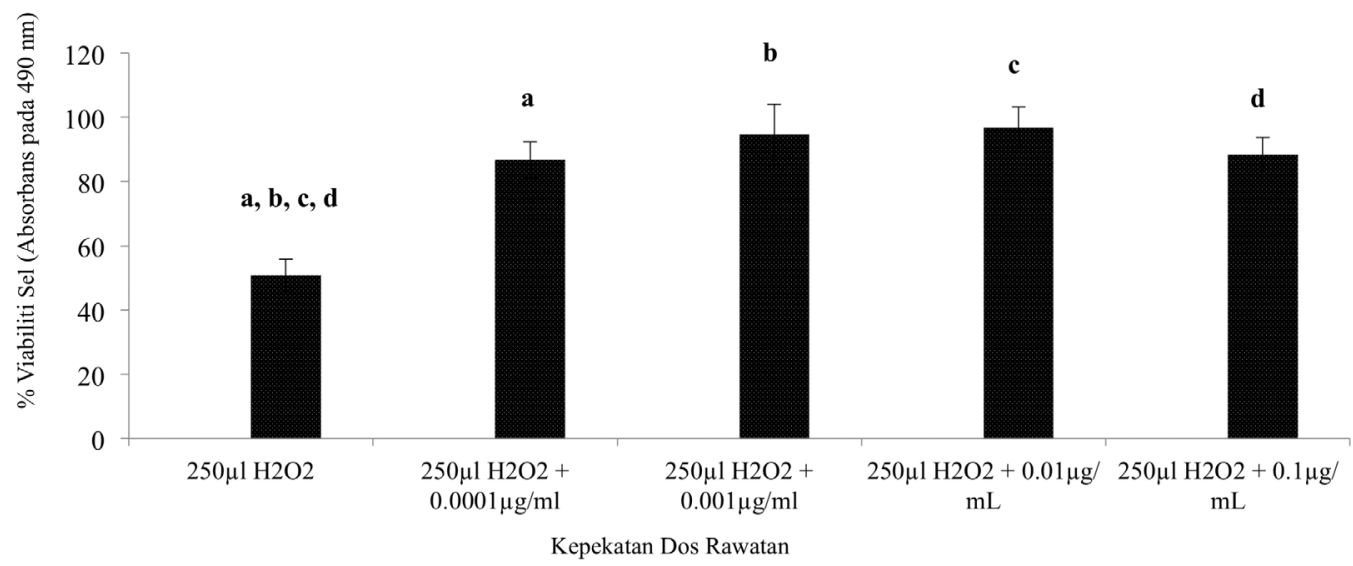

Kumpulan yang mempunyai abjad yang sama menunjukkan perbezaan yang signifikan $(p<0.05)$

RAJAH 2. Graf kesan toksisiti polifenol minyak kelapa dara terhadap sel MC3T3-E1 yang ditentukan dengan menggunakan asai MTS. Sel MC3T3-E1 didedahkan dengan $250 \mu \mathrm{M} \mathrm{H}_{2} \mathrm{O}_{2}$ selama 1 jam sebelum dirawat dengan kepekatan menurun polifenol selama 24 jam 
menunjukkan kesan toksik, tiga dos telah dipilih untuk digunakan di dalam kajian seterusnya. Dos yang dipilih adalah dos $0.01 \mu \mathrm{g} / \mathrm{mL}$ sebagai dos pertengahan dan 0.0001 $\mu \mathrm{g} / \mathrm{mL}$ sebagai dos rendah PF. Dos PF pada kepekatan 1 $\mu \mathrm{g} / \mathrm{mL}$ pula dipilih sebagai dos tinggi adalah berdasarkan nisbah kepekatan yang telah dikira.

Kesan $\mathrm{H}_{2} \mathrm{O}_{2}$ dan $\mathrm{PF}$ terhadap enzim superoksida dismutase (SOD) pada sel MC3T3-E1 ditunjukkan pada Rajah 3. Keputusan kajian menunjukkan dedahan sel MC3T3-E1 pada kepekatan $250 \mu \mathrm{M} \mathrm{H}_{2} \mathrm{O}_{2}$ selama 1 jam menurunkan aktiviti SOD secara signifikan $(p<0.05)$ berbanding kumpulan kawalan dan kumpulan PF. Walau bagaimanapun, selepas diberi rawatan polifenol selama 24 jam pada kepekatan 0.01 dan $0.0001 \mu \mathrm{g} / \mathrm{mL}$ dapat meningkatkan aktiviti SOD secara signifikan $(p<0.05)$ berbanding kumpulan $\mathrm{H}_{2} \mathrm{O}_{2}$ sahaja. Didapati juga bahawa pos-rawatan polifenol kepada sel MC3T3-E1 dapat meningkatkan aktiviti SOD setara dengan kumpulan kawalan.

Kesan $\mathrm{H}_{2} \mathrm{O}_{2}$ dan rawatan $\mathrm{PF}$ terhadap aktiviti enzim glutation peroksidase (GPx) pada sel MC3T3-E1 ditunjukkan pada Rajah 4. Keputusan kajian menunjukkan dedahan sel MC3T3-E1 pada kepekatan $250 \mu \mathrm{M} \mathrm{H}_{2} \mathrm{O}_{2}$ selama 1 jam menurunkan aktiviti GPx secara signifikan $(p<0.05)$ berbanding kumpulan kawalan dan kumpulan polifenol berkepekatan $1 \mu \mathrm{g} / \mathrm{mL}$. Selain peningkatan secara signifikan $(p<0.05)$ aktiviti GPx pada kumpulan $1 \mu \mathrm{g} /$ $\mathrm{mL}$ PF berbanding kumpulan $250 \mu \mathrm{M} \mathrm{H}_{2} \mathrm{O}_{2}$, peningkatan kumpulan $1 \mu \mathrm{g} / \mathrm{mL}$ PF juga setara dengan kumpulan kawalan.

Kesan $\mathrm{H}_{2} \mathrm{O}_{2}$ dan rawatan $\mathrm{PF}$ terhadap enzim katalase (CAT) pada sel MC3T3-E1 ditunjukkan pada Rajah 5. Keputusan kajian menunjukkan dedahan sel MC3T3-E1 pada kepekatan $250 \mu \mathrm{M} \mathrm{H}_{2} \mathrm{O}_{2}$ selama 1 jam menurunkan aktiviti CAT secara signifikan $(p<0.05)$ berbanding kumpulan kawalan dan kumpulan PF. Walau bagaimanapun, selepas diberi rawatan polifenol selama 24 jam pada kepekatan 1 dan $0.01 \mu \mathrm{g} / \mathrm{mL}$ dapat meningkatkan aktiviti CAT secara signifikan $(p<0.05)$ berbanding kumpulan $\mathrm{H}_{2} \mathrm{O}_{2}$ sahaja. Didapati juga bahawa pos-rawatan polifenol kepada sel MC3T3-E1 dapat meningkatkan aktiviti CAT setara dengan kumpulan kawalan.

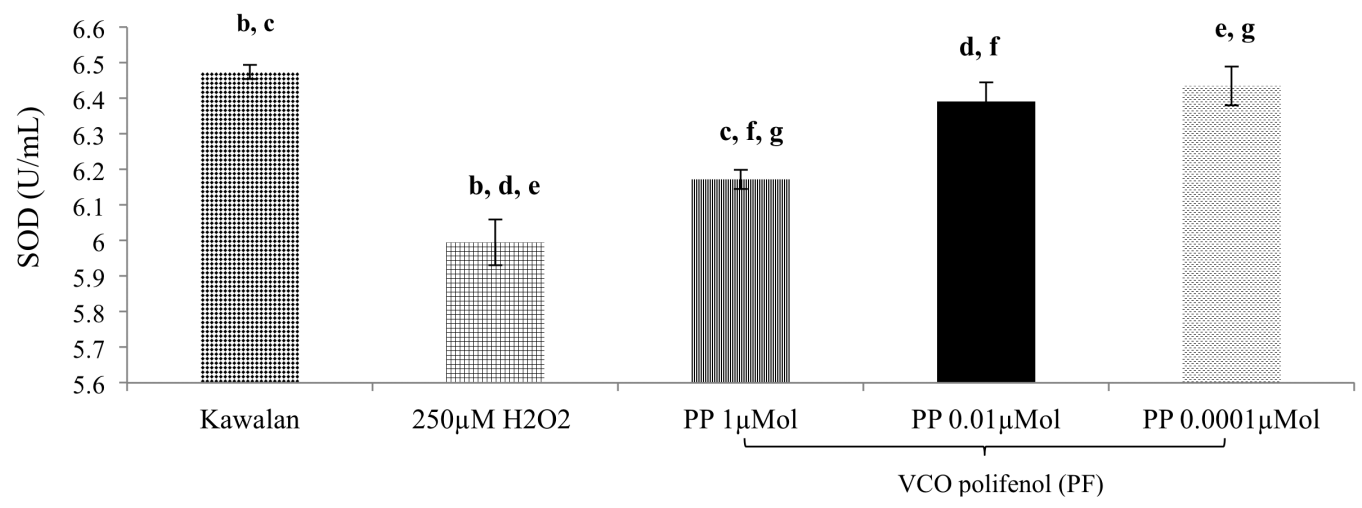

Kumpulan yang mempunyai abjad yang sama menunjukkan perbezaan yang signifikan $(\mathrm{p}<0.05)$.

RAJAH 3. Kesan $\mathrm{H}_{2} \mathrm{O}_{2}$ dan PF terhadap aktiviti SOD di dalam sel MC3T3-E1. Sel MC3T3-E1 didedahkan dengan $250 \mu \mathrm{M} \mathrm{H}_{2} \mathrm{O}_{2}$ selama 1 jam sebelum dirawat dengan PF berkepekatan 1,0.01 dan $0.0001 \mu \mathrm{g} / \mathrm{mL}$ selama 24 jam

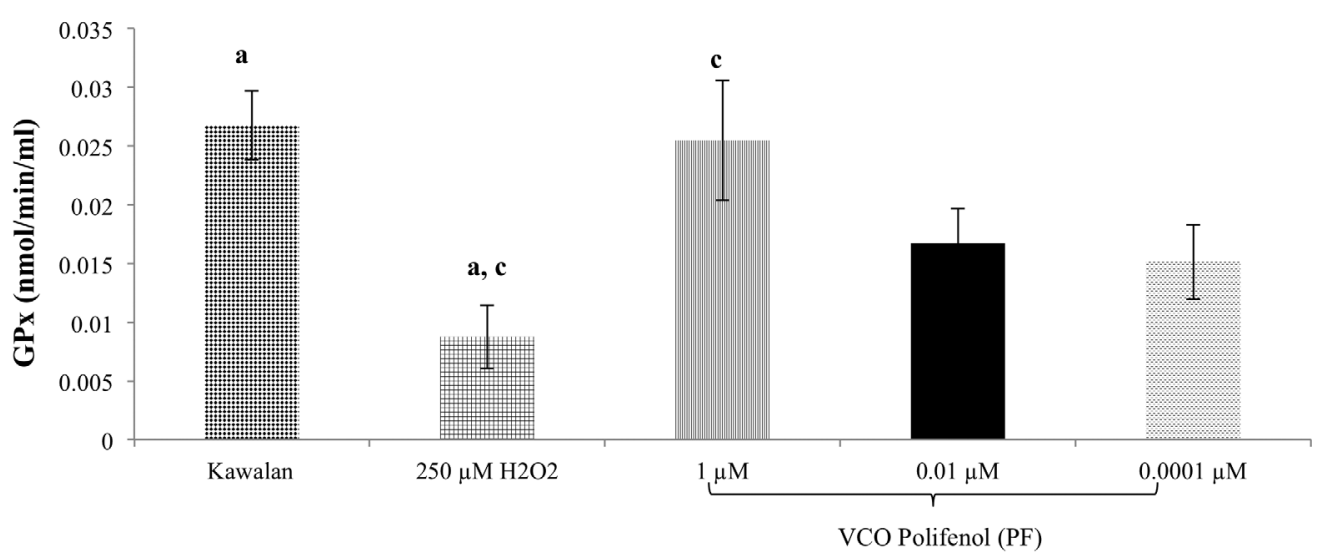

Kumpulan yang mempunyai abjad yang sama menunjukkan perbezaan yang signifikan $(p<0.05)$

RAJAH 4. Kesan $\mathrm{H}_{2} \mathrm{O}_{2}$ dan PF terhadap aktiviti GPx di dalam sel MC3T3-E1. Sel MC3T3-E1 didedahkan dengan 250 $\mu \mathrm{M} \mathrm{H}_{2} \mathrm{O}_{2}$ selama 1 jam sebelum dirawat dengan PF berkepekatan 1,0.01 dan $0.0001 \mu \mathrm{g} / \mathrm{mL}$ selama 24 jam 


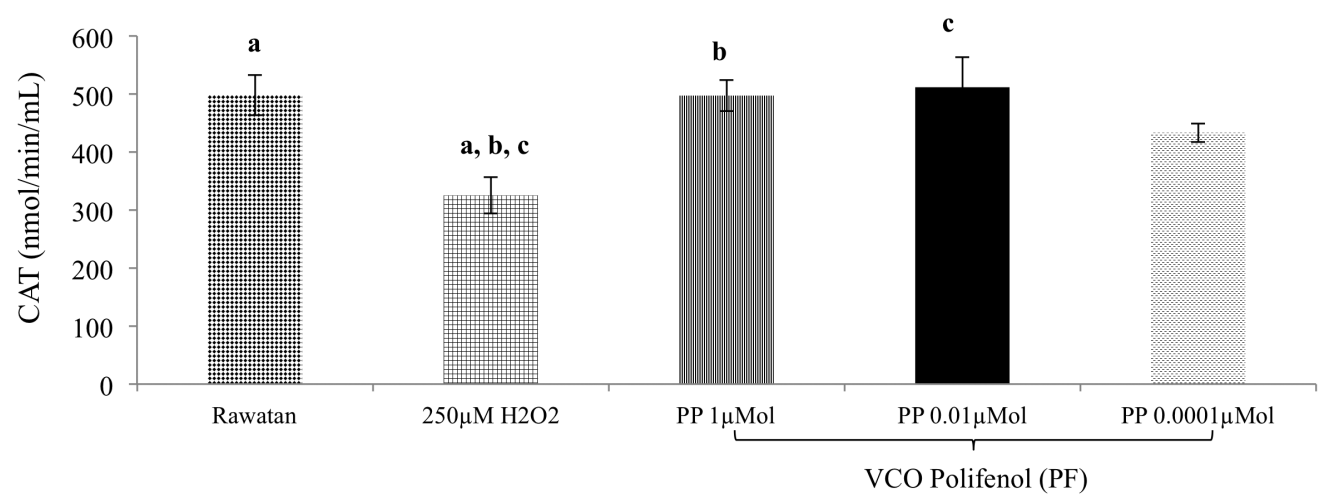

Kumpulan yang mempunyai abjad yang sama menunjukkan perbezaan yang signifikan $(p<0.05)$

RAJAH 5. Kesan $\mathrm{H}_{2} \mathrm{O}_{2}$ dan PF terhadap aktiviti CAT di dalam sel MC3T3-E1. Sel MC3T3-E1 didedahkan dengan $250 \mu \mathrm{MnH}_{2} \mathrm{O}_{2}$ selama 1 jam sebelum dirawat dengan PF berkepekatan 1, $0.01 \mathrm{dan} 0.0001 \mu \mathrm{g} / \mathrm{mL}$ selama 24 jam

Kesan $\mathrm{H}_{2} \mathrm{O}_{2}$ dan rawatan polifenol yang diekstrak daripada minyak kelapa dara terhadap aras MDA pada sel MC3T3-E1 ditunjukkan pada Rajah 6. Keputusan kajian menunjukkan dedahan sel MC3T3-E1 pada kepekatan 250 $\mu \mathrm{M} \mathrm{H} \mathrm{H}_{2} \mathrm{O}_{2}$ selama 1 jam meningkatkan aras MDA secara signifikan $(p<0.05)$ berbanding kumpulan kawalan dan kumpulan $0.01 \mu \mathrm{g} / \mathrm{mL}$ PF. Walau bagaimanapun, selepas diberi rawatan PF selama 24 jam pada kepekatan $0.01 \mu \mathrm{g} /$ $\mathrm{mL}$ dapat menurunkan aras MDA secara signifikan $(p<0.05)$ berbanding kumpulan $\mathrm{H}_{2} \mathrm{O}_{2}$ sahaja, kumpulan kawalan dan kumpulan $1 \mu \mathrm{g} / \mathrm{mL}$ PF. Didapati juga bahawa pos-rawatan polifenol kepada sel MC3T3-E1 dapat meningkatkan aras MDA setara dengan kumpulan kawalan.

\section{PERBINCANGAN}

Dalam kajian ini, hidrogen peroksida $\left(\mathrm{H}_{2} \mathrm{O}_{2}\right)$ digunakan sebagai bahan toksik untuk memberi aruhan tekanan oksidatif kepada sel MC3T3-E1. $\mathrm{H}_{2} \mathrm{O}_{2}$ terhasil daripada pelbagai proses di dalam badan termasuklah tindak balas dismutasi anion superoksida $\left(\mathrm{O}_{2}^{-}\right)$yang terhasil daripada proses respirasi mitokondria, sama ada secara spontan atau ditukarkan oleh enzim superoksida dismutase. Keputusan kajian mendapati $\mathrm{H}_{2} \mathrm{O}_{2}$ pada kepekatan yang tinggi, iaitu melebihi $250 \mu \mathrm{M}$ mempunyai kesan toksik dan menjejaskan viabiliti sel MC3T3-E1 setelah didedahkan selama 1 jam. Kajian ini selari dengan kajian $\mathrm{Xu}$ et al. (2011), yang mendapati bahawa sel selanjar menyerupai osteoblas mencit (MC3T3-E1) mengalami kecederaan maut setelah didedahkan dengan dos tinggi $\mathrm{H}_{2} \mathrm{O}_{2}(400-800 \mu \mathrm{M})$ selama 4 hingga 6 jam, manakala dos yang rendah pula $(0-200 \mu \mathrm{M})$ tidak menjejaskan viabiliti sel ini. Zhang et al. (2012) juga mendapati bahawa $\mathrm{H}_{2} \mathrm{O}_{2}$ berkepekatan tinggi $(0.3 \mathrm{mM})$ merangsang tekanan oksidatif dan menyebabkan kematian sel MC3T3-E1. Di samping itu, kajian oleh Nizar et al. (2012) juga menunjukkan kepekatan dos $\mathrm{H}_{2} \mathrm{O}_{2}$ melebihi $200 \mu \mathrm{M}$ menjejaskan vialibiti sel. Terjejasnya viabiliti sel MC3T3-E1 berikutan terdedah kepada $\mathrm{H}_{2} \mathrm{O}_{2}$ adalah bergantung kepada bersandaran-dos (Linares et al. 2009)

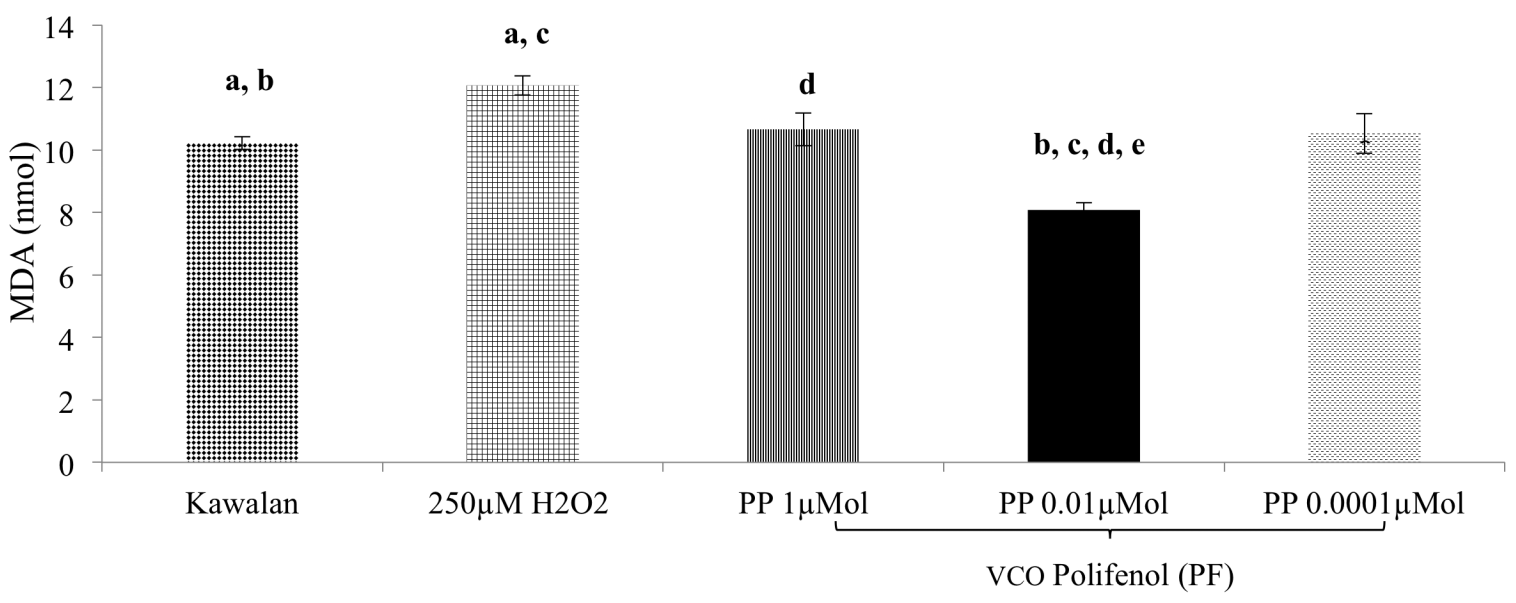

Kumpulan yang mempunyai abjad yang sama menunjukkan perbezaan yang signifikan $(p<0.05)$

RAJAH 6. Kesan $\mathrm{H}_{2} \mathrm{O}_{2}$ dan PF terhadap aras MDA di dalam sel MC3T3-E1. Sel MC3T3-E1 didedahkan dengan $250 \mu \mathrm{M} \mathrm{H}_{2} \mathrm{O}_{2}$ selama 1 jam sebelum dirawat dengan PF berkepekatan 1, $0.01 \mathrm{dan} 0.0001 \mu \mathrm{g} / \mathrm{mL}$ selama 24 jam 
dan bersandaran-dos dan bersandaran-masa (Park et al. 2005; Xu et al. 2011).

Dalam kajian ini, sel MC3T3-E1 dibezakan dahulu selama 15 hari sebelum didedahkan kepada $\mathrm{H}_{2} \mathrm{O}_{2}$. Osteoblast atau sel menyerupai osteoblas didapati lebih cenderung mengalami apoptosis selepas proses pembezaan, dengan meningkatkan aras fragmentasi DNA dan ekspresi gen pro-apoptotik seperti Bcl-2 (Pereira et al. 2001; Zalavras et al. 2003). Kajian Fatokun et al. (2008) menunjukkan sel MC3T3-E1 yang mengalami pembezaan lebih sensitif kepada $\mathrm{H}_{2} \mathrm{O}_{2}$ berbanding sel yang belum membeza. Ini juga berlaku pada jenis sel lain seperti dalam kajian Chodimella et al. (2005) yang menunjukkan sel selanjar neuronal (NSC34D) yang mengalami pembezaan sepenuhnya lebih sensitif kepada nitrik oksida berbanding sel yang tidak membeza sepenuhnya.

Selepas dieram dengan $\mathrm{H}_{2} \mathrm{O}_{2}$ selama 1 jam, sel MC3T3-E1 mengalami kematian sebanyak 50\%. Kajian ini selari dengan kajian dibuat oleh Lee et al. (2001) yang menunjukkan viabiliti sel MC3T3-E1 menurun secara signifikan selepas didedahkan pada $\mathrm{H}_{2} \mathrm{O}_{2}$ dan $\mathrm{FeSO}_{4}$ selama 24 jam, tetapi meningkat setelah rawatan genistein diberikan selama 6 jam kemudian. Kajian yang dibuat oleh Park et al. (2003) pula menunjukkan rawatan awal polifenol teh hijau (GtPP) pada dos $200 \mu \mathrm{M} / \mathrm{mL}$ selama 1 jam pada sel osteoblas dapat mengurangkan kesan toksisiti pada sel yang didedahkan dengan 50 dan $100 \mathrm{mmol} / \mathrm{L} \mathrm{H}_{2} \mathrm{O}_{2}$ selama 24 jam berbanding kumpulan sel kawalan $\left(\mathrm{H}_{2} \mathrm{O}_{2}\right.$ sahaja). Kajian ini telah disokong oleh Hagiwara et al. (2011) yang mendapati hidroksitirosol iaitu polifenol daripada minyak zaiton meningkatkan viabiliti sel MC3T3-E1 sebanyak 60\% setelah menerima aruhan $\mathrm{H}_{2} \mathrm{O}_{2}$ Keadaan ini dapat dijelaskan bahawa sel-sel yang masih hidup akan berproliferasi semula dan rawatan PF ke atas sel dapat mempercepatkan lagi proses proliferasi tersebut. Ini menunjukkan polifenol yang diekstrak daripada minyak kelapa dara sangat aktif dan memberi rawatan secara signifikan kepada sel yang mengalami tekanan oksidatif. Walau bagaimanapun kajian ini agak berbeza dengan kajian terdahulu apabila rawatan PF pada sel diberi selepas sel didedahkan pada tekanan oksidatif, sebaliknya kajian terdahulu telah memberi rawatan kepada sel terlebih dahulu sebelum didedahkan kepada tekanan oksidatif. Melalui kaedah ini, dapat disimpulkan bahawa PF yang diekstrak daripada minyak kelapa dara bukan sahaja memberi perlindungan kepada tulang tetapi juga dapat merawat kerosakan pada tulang dengan membantu meningkatkan proses selular proliferasi pada sel osteoblas.

Ketidakseimbangan antara osteoblas dan osteoklas disebabkan oleh peningkatan resorpsi tulang melebihi penbentukan tulang, menyebabkan terjadinya penyakit degenerasi tulang termasuk osteoporosis. Banyak kajian telah membuktikan bahawa tekanan oksidatif yang tinggi mempengaruhi terjadinya osteoporosis, disebabkan oleh proses penuaan dan defisiensi estrogen (Baek et al. 2010; Maggio et al. 2003). Tekanan oksidatif terhasil daripada spesies oksigen reaktif (ROS) yang berlebihan, boleh menyebabkan kerosakan dan kemusnahan kepada pelbagai jenis tisu. Hidrogen peroksida $\left(\mathrm{H}_{2} \mathrm{O}_{2}\right)$ merupakan sumber utama spesies oksigen reaktif (ROS) yang seringkali digunakan sebagai penjana ROS di dalam model tekanan oksidatif in vitro (Satoh et al. 1996). Disebabkan oleh $\mathrm{H}_{2} \mathrm{O}_{2}$ mempunyai separa-hidup yang panjang dan berkebolehan untuk masuk ke dalam membran biologi, ia mempunyai ciri yang bersesuaian yang bertindak ke atas isyarat luar (intra) dan dalam (inter) selular (Denisova et al. 2001).

Penghasilan radikal bebas boleh mengganggu mekanisme pertahanan antioksidan. Kajian ini menunjukkan sel MC3T3-E1 yang dieram selama 1 jam dengan $250 \mu \mathrm{M} \mathrm{H}_{2} \mathrm{O}_{2}$ mengalami penurunan aktiviti SOD, GPX dan CAT secara signifikan berbanding kumpulan kawalan. Kajian ini selari dengan kajian Kamat et al. (2000) yang mendapati bahawa $\mathrm{H}_{2} \mathrm{O}_{2}$ secara signifikan menurunkan aktiviti SOD, GPx dan CAT. Kajian yang dilakukan oleh Nizar et al. (2012) pula menunjukkan pendedahan sel osteoblas pada $490 \mu \mathrm{M} \mathrm{H}_{2} \mathrm{O}_{2}$ selama 2 jam telah menurunkan aktiviti SOD, GPx dan CAT secara signifikan berbanding kumpulan kawalan. Kajian lain juga mendapati pendedahan sel selanjar menyerupai mencit (MC3T3-E1) pada kepekatan $400 \mu \mathrm{M} \mathrm{H}_{2} \mathrm{O}_{2}$ juga menurunkan antiviti SOD (Xu et al. 2011). Kajian ini selari dengan beberapa kajian yang telah mengaitkan kesan buruk $\mathrm{H}_{2} \mathrm{O}_{2}$ terhadap enzim antioksidan endogenus. Antaranya adalah kajian yang dibuat oleh Wang et al. (2010) mendapati bahawa rawatan $400 \mu \mathrm{M} \mathrm{H}_{2} \mathrm{O}_{2}$ selama 12 jam pada sel HUVEC menurunkan antiviti GPx sebanyak 52.76\%. Wu et al. (2006) pula mendapati pendedahan $150 \mu \mathrm{M} \mathrm{H}_{2} \mathrm{O}_{2}$ selama 1 jam ke atas sel selanjar feokromositoma (PC12) telah menurunkan aktiviti enzim glutation peroksidase (GPx), superoksida dismutase (SOD) dan katalase (CAT) berbanding kumpulan kawalan negatif.

Kajian ini menunjukkan rawatan PF daripada VCO membantu meningkatkan mekanisme pertahanan aktiviti enzim antioksidan daripada spesies oksigen reaktif (ROS) dan menghalang peroksidasi lipid. Meningkatnya aktiviti enzim antioksidan menandakan kurangnya pembentukan radikal hidroksil $\left(\mathrm{OH}^{-}\right)$. Kajian in vivo oleh Nevin dan Rajamohan (2006) menunjukkan tikus yang diberi VCO meningkatkan aras SOD, GPx dan CAT berbanding minyak kopra dan minyak minyak kacang tanah.

MDA merupakan produk akhir proses peroksidasi lipid dan selalu digunakan untuk mengukur aras peroksidasi lipid. Secara umumnya, peroksidasi lipid adalah proses pro-oksidan seperti radikal bebas atau spesies bukan radikal penyerang lipid mengandungi ikatan dua karbon, terutamanaya asid lemak politaktepu (PUFAs), yang melibatkan keluarnya atom hidrogen daripada rantaian karbon PUFA. Radikal lipid yang terbentuk kemudian bercantum dengan oksigen membentuk radikal lipid peroksil dan hidroperoksid (Yin et al. 2011). Kajian ini selari dengan kajian Zhang et al. (2012) yang mendapati rawatan $\mathrm{H}_{2} \mathrm{O}_{2}$ pada kepekatan $0.3 \mathrm{mM}$ selama 24 jam telah meningkatkan aras MDA secara signifikan. Kajian Rupesh 
et al. (2008) pula menunjukkan peningkatan aras MDA pada sel selanjar kulit fibroblas (AH927) setelah dieram dengan $0.5 \mathrm{mM} \mathrm{H}_{2} \mathrm{O}_{2}$ selama 24 jam. Kajian in vivo menunjukkan bahawa paras peroksidasi lipid (MDA) meningkat dalam homogenat tisu femur tikus yang diovariektomi (Nadia et al. 2014).

Dalam kajian ini, PF minyak kelapa dara telah menunjukkan kesan positif apabila PF dapat menurunkan aras MDA selepas aruhan $\mathrm{H}_{2} \mathrm{O}_{2}$. Ini bertepatan dengan kajian Scalbert et al. (2005) yang menyatakan bahawa aktiviti antioksidan polifenol adalah melalui tindakan hidroksil fenolik yang mudah mendermakan atom hidrogen $(\mathrm{H})$ kepada radikal peroksil lipid (FAOO-), lalu menghasilkan spesies lipid yang lebih stabil. Apabila atom $\mathrm{H}$ telah didermakan, polifenol menjadi radikal bebas yang secara relatifnya tidak reaktif kerana elektron tidak berpasangan menjadikan ia tidak setempat ke dalam gelang aromatik. Kajian ini selari dengan kajian Nevin dan Rajamohan (2006) yang menunjukkan tikus yang diberi PF daripada vCO berjaya menghalang pembentukan peroksidasi lipid. Kajian in vivo yang dibuat oleh Abujazia et al. (2012) menunjukkan suplementasi minyak kelapa dara menurunkan aras MDA pada tikus yang telah diovariektomi. Minyak kelapa dara juga menurunkan aras MDA pada tikus berkolesterol tinggi (Nevin \& Rajamohan 2008). Selain itu, minyak kelapa dara menurunkan aras MDA pada tikus yang telah diberi rawatan alkohol (Dosumu et al. 2010).

\section{KESIMPULAN}

Kesimpulan yang dapat dibuat dalam kajian ini adalah polifenol daripada minyak kelapa dara $(\mathrm{PF})$ merupakan antioksidan yang aktif, berpotensi untuk meningkatkan kadar enzim antioksidan dan menurunkan lipid peroksida pada sel MC3T3-E1 yang telah diaruh dengan $\mathrm{H}_{2} \mathrm{O}_{2}$. Oleh kerana tiada dos yang menjadi toksik kepada sel MC3T3-E1, polifenol VCO juga sesuai dijadikan rawatan sampingan untuk merawat dan menghalang osteoporosis pascamenopaus daripada berlaku.

\section{PENGHARGAAN}

Setinggi-tinggi penghargaan buat pihak UKM yang telah memberikan dana bagi penyelidikan ini serta semua kakitangan Jabatan Farmakologi terutamanya Encik Fadhlullah Zuhair, Puan Juliana Abdul Hamid, Puan Nurul Hafizah Abas dan Puan Farhana Mohd Fauzi atas bantuan teknikal semasa kajian ini dijalankan.

\section{RUJUKAN}

Abujazia, M.A., Norliza, M., Ahmad, N.S. \& Ima Nirwana, S. 2012. The effects of virgin coconut oil on bone oxidative status in ovariectomized rats. Evidence-Based Complementary \& Alternative Medicine 2012: 525079. http:// dx.doi.org/10.1155/2012/525079.

Altindag, O., Erel, O., Soran, N., Celik, H. \& Selek, S. 2008. Total oxidative/antioxidative status and relation to bone mineral density in osteoporosis. Rheumatology International 28(4): 317-321.
Arora, R., Chawla, R., Marwah, R., Arora, P., Sharma, R.K., Kaushik, V., Goel, R., Kaur, A., Silambarasan, M., Tripathi, R.P. \& J.R. Bhardwaj. 2011. Potential of complementary and alternative medicine in preventive management of novel H1N1 flu (Swine flu) pandemic: Thwarting potential disasters in the Bud. Evidence-Based Complementary \& Alternative Medicine. 2011: 586506. doi:10.1155/2011/586506.

Baek, K.H., Oh, K.W., Lee, W.Y., Lee, S.S., Kim, M.K., Kwon, H.S., Rhee, E.J., Han J.H., Song, K.H. \& Cha, B.Y. 2010. Association of oxidative stress with postmenopausal osteoporosis and the effects of hydrogen peroxide on osteoclast formation in human bone marrow cell cultures. Calcified Tissue International 87(3): 226-235.

Barnabé, W., de Mendonça Neto, T., Pimenta, F.C., Pegoraro, L.F. \& Scolaro, J.M. 2004. Efficacy of sodium hypochlorite and coconut soap used as disinfecting agents in the reduction of denture stomatitis, Streptococcus mutans and Candida albicans. Journal of Oral Rehabilitation 31(5): 453-459.

Chodimella, R., Anderson, J., Hong, Y. \& Bishop, A. 2005. Nitric Oxide (NO) Sensitivity and Differentiation Status in Motor Neurons (Abstract). Washington, DC: Society for Neuroscience.

Cosman, F., de Beur, S.J.,LeBoff, M.S., Lewiecki, E.M., Tanner, B., Randall, S. \& Lindsay, R. 2014. Clinician's guide to prevention and treatment of osteoporosis. Osteoporosis International 25(10): 2359-2381.

Danielle, A.C. \& Jiang, J.X. 2015. Reactive oxygen species and oxidative stress in osteoclastogenesis, skeletal aging and bone diseases. Journal of Bone and Mineral Metabolism 33(4): 359-370.

Daroszewska,A. 2015. Prevention and treatment of osteoporosis in women: An update. Obstetrics, Gynaecology \& Reproductive Medicine 25(7): 181-187.

Denisova, N.A., Cantuti-Castelvetri, I., Hassan, W.N., Paulson, K.E. \& Joseph, J.A. 2001. Role of membrane lipids in regulation of vulnerability to oxidative stress in PC12 cells: implication for aging. Free Radical Biology and Medicine 30(6): 671-678

Dosumu, O.O., Duru, F.I.O., Osinuba, A.A., Oremosu, A.A. \& Noronha, C.C. 2010. Influence of virgin coconut oil (VCNO) on oxidative stress, serum testosteron and gonadotropic hormones $(\mathrm{FSH}, \mathrm{LH})$ in chronic ethanol ingestion. Agriculture \& Biology Journal of North America 1(6): 1126-1132.

Fatokun, A.A., Stone, T.W. \& Smith, R.A. 2008. Responses of differentiated MC3T3-E1 osteoblastic cells to reactive oxygen species. European Journal of Pharmacology 587(13): $35-41$.

Hagiwara, K., Goto, T., Araki, M., Miyazaki, H. \& Hagiwara, H. 2011. Olive polyphenol hydroxytyrosol prevents bone loss. European Journal of Pharmacology 662(1-3): 78-84.

Kamat,J.P., Boloor, K.K., Devasagayam,T.P.A.\& Venkatachalam, S.R. 2000. Antioxidant properties of asparagus racemosus against damage induced by gamma-radiation in rat liver mitochondria. Journal of Ethnopharmacology 71(3): 425 435.

Lee, Y.S., Chen, X. \& Anderson, J.J.B. 2001. Physiological concentrations of genistein stimulate the proliferation and protect against free radical-induced oxidative damage of MC3T3-E1 osteoblast-like cells. Nutrition Research 21(9): 1287-1298.

Linares, G.R., Xing, W., Govoni, K.E., Chen, S. \& Mohan, S. 2009. Glutaredoxin 5 regulates osteoblast apoptosis ny protecting against oxidative stress. Bone 44(5): 795-804. 
Maggio, D., Barabani, M.,Pierandrei, M.,Polidori, M.C., Catani, M., Mecocci, P., Senin, U., Pacifici, R. \& Cherubini, A. 2003. Marked decrease in plasma antioxidants in aged osteoporotic women: results of a cross-sectional study. Journal of Clinical Endocrinology \& Metabolism 88(4): 1523-1527.

Manisha, D. \& Shyamapada, M. 2011. Coconut (Cocos nucifera L.: Arecaceae): In health promotion and disease prevention. Asian Pacific Journal of Tropical Medicine 4(3): 241-247.

Marina, A.M., Che Man, Y.B. \& Nazimah, A.H. 2009. Chemical properties of virgin coconut oil. Journal of the American Oil Chemists' Society 86(4): 301-307.

McNamara, L.M. 2010. Perpective on post-menopausal osteoporosis: Establishing an interdisciplinary understanding of the sequence of events from the molecular level to whole bone fracktures. Journal of the Royal Society Interface 7(44): 353-372.

Morton, D.J., Barrett-Connor, E.L. \& Schneider, D.L. 2001. Vitamin C supplement use and bone mineral density in postmenopausal women. Journal of Bone Mineral Research 16(1): 135-140.

Muhammad, Z.M., Ahmad, N.S., Norazlina, M., Norliza, M. \& Ima-Nirwana, S. 2010. Beneficial effects of vitamin E isomer supplementation on static and dynamic bone histomorphometry parameters in normal male rats. Journal of Bone and Mineral Metabolism 28(5): 503-509.

Nadia, M.E. \& Ahmad, N.S. 2014. Time and dose-dependent effects of Labisia pumila on bone oxidative status of postmenopausal osteoporosis rat model. Nutrients 6(8): 3288-3302.

Nevin, K.G. \& Rajamohan, T. 2006. Virgin coconut oil supplemented diet increased the antioxidant status in rats. Food Chemistry 99(2): 260-266.

Nevin, K.G. \& Rajamohan, T. 2008. Influence of virgin coconut oil on blood coagulation factors, lipid levels and LDL oxidation in cholesterol fed Sprague-Dawley rats. European Journal of Clinical Nutrition Metabolism 3: 1-8.

Nevin, K.G. \& Rajamohan, T. 2005. Virgin coconut oil supplemented diet increases the antioxidant status in rats. Food Chemistry 99(2): 260-266.

Nevin, K.G. \& Rajamohan, T. 2004. Beneficial effects of virgin coconut oil on lipid parameters and in vitro LDL oxidation. Clinical Biochemistry 37(9): 830-835.

Nizar, A.M., Norazlina, M. \& Ahmad, N.S. 2012. Effects of low-dose versus high doses $\gamma$-tocotrienol on the bone cells exposed to the hydrogen peroxide-induced oxidative stress and apoptosis. Evidence-Based Complementary \& Alternative Medicine 2012: 680834. http://dx.doi. org/10.1155/2012/680834.

Norliza, M., Douglas, A.L., Ahmad, N.S., Norazlina, M. \& Ima-Nirwana, S. 2012. Two different isomers of vitamin E prevent bone loss in postmenopausal osteoporosis rat model. Evidence-Based Complementary \& Alternative Medicine 2012: 161527. https://doi.org/10.1155/2012/161527.

Oyi, A.R., Onaolapo, J.A. \& Obi, R.C. 2010. Formulation and antimicrobial studies of coconut (Cocos nucifera Linne) oil. Research Journal of Applied Sciences, Engineering and Technology 2(2): 133-137.

Park, B.G., Yoo, C.I., Kim, H.T., Kwon, C.H. \& Kim, Y.K. 2005. Role of mitogen- activated protein kinases in hydrogen peroxide-induced cell death in osteoblastic cells. Toxicology 215(1-2): 115-125.

Park, Y.H., Wan, D.W., Suh, H., Ryu, G.H., Hyon, S.H., Cho, B.K. \& Park, J.C. 2003. Protective effects of green tea polyphenol against reactive oxygen species-induced oxidative stress in cultures rat calvarial osteoblast. Cell Biology \& Toxicology 19(5): 325-337.

Pereira, R.M., Delany, A.M. \& Canalis, E. 2001. Cortisol inhibits the differentiation and apoptosis of osteoblasts in culture. Bone 28(5): 484-490.

Rupesh, D., Chitrangada, A., Bindu, P.C. \& Kundu, S.C. 2008. Antioxidant potential of silk protein sericin against hydrogen peroxide-induced oxidative stress in skin fibroblasts. BMP Reports 41(3): 236-241.

Satoh, I., Sakai, N., Enokido, Y., Uchiyama, Y. \& Hatanaka, H. 1996. Free radical independent protection by nerve growth factor and Bcl-2 of PC12 cells from hydrogen peroxidetriggered apoptosis. Journal of Biochemistry 120: 540-546.

Scalbert, A., Johnson, I.T. \& Saltmarsh, M. 2005. Polyphenols: Antioxidants and beyond. American Journal of Clinical Nutrition 81(1): 215S-217S.

Sendur, O.F., Turan, Y., Tastaban, E. \& Serter, M. 2009. Antioxidant status in patients with osteoporosis: A controlled study. Joint Bone Spine 76(5): 514-518.

Sosnowska, J. \& Balslev, H. 2009. American palm ethnomedicine: A metaanalysis. Journal of Ethnobiology and Ethnomedicine 5: 43. https://doi.org/10.1186/1746-4269-5-43.

Taheri, J.B., Espineli, F.W., Lu, H., Asayesh, M., Bakshi, M. \& Nakhostin, M.R. 2010. Antimicrobial effect of coconut flour on oral microflora: An in vitro study. Research Journal of Biological Sciences 5(6): 456-459.

Wang, Y.K., Hong, Y.J., Wei, M., Wu, Y., Huang, Z.Q., Chen, R.Z. \& Chen, H.Z. 2010. Curculigoside attenuates human umbilicak vein endothelial cell injury induced by $\mathrm{H}_{2} \mathrm{O}_{2}$. Journal of Ethnopharmacology 132(1): 233-239.

Wu, J.H., Xu, C., Shan, C.Y. \& Tan, R.X. 2006. Antioxidant properties and PC12 cell protective effects of APS-1, a polysaccharide from Aloe vera var. Chinensis. Life Science 78(6): 622-630

Xu, Z.S., Wang, X.Y., Xiao, D.M., Hu, L.F., Lu, M., Wu, Z.Y. \& Bian, J.S. 2011. Hydrogen sulfide protects MC3T3-E1 osteoblastic cells against $\mathrm{H} 2 \mathrm{O} 2$-induced oxidative damage - implications for the treatmet of osteoporosis. Free Radical Biology \& Medicine 50(10): 1314-1323.

Yin, H., Xu, L. \& Porter, N.A. 2011. Free radical lipid peroxidation: Mechanisms and analysis. Chemical Reviews 111(10): 5944-5972.

Zalavras, C., Shah, S., Birnbaum, M.J. \& Frenkel, B. 2003. Role of apoptosis in glucocorticoid-induced osteoporosis and osteonecrosis. Critical Reviews in Eukaryotic Gene Expression 13(2-4): 221-235.

Zhang, J.K., Yang, L., Meng, G.L., Fang, J., Chen, J.Z., He, Q.Z., Chen, S., Fan, J.Z., Luo, Z.J. \& Liu, J. 2012. Protective effects of tetrehydroxystilbene glucoside against hydrogen peroxideinduced dysfunction and oxidative stress in osteoblastic MC3T3-E1 cell. European Journal of Pharmacology 689: 31-37.

Zil Hayatullina, Norliza, M., Norazlina, M. \& Ima-Nirwana, S. 2012. Virgin coconut oil supplementation prevents bone loss in osteoporosis rat model. Evidence-Based Complementary and Alternative Medicine 2012: 237236.

Jabatan Farmakologi

Fakulti Perubatan

Universiti Kebangsaan Malaysia 
50300 Kuala Lumpur, Wilayah Persekutuan

Malaysia

*Pengarang untuk surat-menyurat; email: norliza_ssp@ppukm. ukm.edu.my
Diserahkan: 3 April 2018

Diterima: 5 Jun 2018 